Original Research Article

\title{
Bronchodilator activity of Ocimum sanctum Linn. (tulsi) in mild and moderate asthmatic patients in comparison with salbutamol: a single- blind cross-over study
}

\author{
Vinaya M. ${ }^{1 *}$, Kudagi B. L. ${ }^{2}$, Mohammed Ameeruddin Kamdod ${ }^{3}$, Mallikarjuna Swamy ${ }^{4}$
}

\begin{abstract}
${ }^{1}$ Department of Pharmacology, Adichunchanagiri Institute of Medical Sciences, Bellur, Mandya, Karnataka, India ${ }^{2}$ Department of Pharmacology, Narayana Medical College, Nellore, Andhra Pradesh, India ${ }^{3}$ Department of Pharmacology, SDM Medical College, Dharwad, Karnataka, India ${ }^{4}$ Department of General Medicine, Navodaya Medical College, Raichur, Karnataka, India
\end{abstract}

Received: 03 February 2017

Accepted: 14 February 2017

*Correspondence to:

Dr. Vinaya M.,

Email:

drmvinaya2016@gmail.com

Copyright: (C) the author(s), publisher and licensee Medip Academy. This is an openaccess article distributed under the terms of the Creative Commons Attribution NonCommercial License, which permits unrestricted noncommercial use, distribution, and reproduction in any medium, provided the original work is properly cited.

\section{ABSTRACT}

Background: Bronchial asthma is one of the commonest chronic inflammatory diseases. The drugs available to treat bronchial asthma such as, beta-2 agonists, though very effective are associated with adverse effects. Therefore, the Ocimum sanctum (Tulsi) which was shown to have antiasthmatic activity in Ayurveda, is evaluated in this study.

Objectives: To evaluate the bronchodilator activity of Ocimum sanctum Linn. in mild and moderate asthma and compare its efficacy with the standard bronchodilator drug, Salbutamol.

Methods: This is a single-blind cross-over study. Capsules of Ocimum sanctum Linn. (200 mg, twice daily) and Salbutamol sulphate (2 mg, twice daily) were administered in 41 patients. Each drug was administered for a period of one week with a washout period of one week between the two drug schedules. FEV and PEFR were recorded in these patients to assess the bronchodilator activity before the drug administration, on $4^{\text {th }}$ and on $7^{\text {th }}$ day of administration of Ocimum sanctum and the parameters obtained were compared with that of the standard drug, Salbutamol.

Results: Ocimum sanctum 200mg twice daily produced significant improvement in both $\mathrm{FEV}_{1}$ and PEFR values, on 4th and $7^{\text {th }}$ day and also produced improvement in symptoms of asthma. On comparing the results with that of Salbutamol $2 \mathrm{mg}$ twice daily, the bronchodilator activity of Ocimum sanctum was found to be less efficacious, where Salbutamol produced very highly significant improvement in $\mathrm{FEV}_{1}$ and PEFR values on both $4^{\text {th }}$ and $7^{\text {th }}$ day.

Conclusions: Our results suggest that Ocimum sanctum Linn. possesses significant bronchodilator activity in mild and moderate bronchial asthma.

Keywords: Bronchodilation, $\mathrm{FEV}_{1}$, Ocimum sanctum, PEFR, Salbutamol

\section{INTRODUCTION}

Bronchial asthma is one of the longest recognized diseases. It has become a public health problem only in the last 30 years and it is now recognized as a common cause of disability, of great economic cost, and of preventable deaths. ${ }^{1}$ The prognosis of asthma remains good with as many as $60 \%-80 \%$ of patients being able to lead normal lives without much disruption. However, $10 \%-20 \%$ of patients continue to have severe attacks throughout their lives. ${ }^{2}$ 
Bronchial asthma is defined as a chronic inflammatory disease of airways that is characterized by increased responsiveness of the tracheobronchial tree to a multiplicity of stimuli. Asthma is an episodic disease, with acute exacerbations interspersed with symptom-free periods. $^{3}$

Asthma currently affects 300 million people worldwide. Female sex, advancing age, usual residence in urban area, lower socio-economic status, history of atopy, and all forms of tobacco smoking were associated with significantly higher odds of having asthma. ${ }^{4}$ In childhood, the incidence is higher in boys than in girls but reverses in the age group 15-50 years and reverses again in the older group when the incidence among men increases. 5

Airway narrowing is the basic pathophysiologic abnormality that determines the functional and symptomatic status of an asthmatic patient. ${ }^{6}$ Asthma is characterized by periodic paroxysms of dyspnea, usually at rest as well on exertion, interspersed with intervals of complete or nearly complete remission, the onset of an attack of asthma is heralded by an unproductive cough and wheeze, followed by the sensations of suffocation and tightness in the chest. Paroxysms occur more commonly in night. Nocturnal breathlessness is a common symptom. Physical signs include, tachypnea, hyperresonance on percussion, inspiratory and expiratory rhonchi and wheezes, decreased breath sounds, and prolonged expiration. ${ }^{5}$ The clinical evaluation of asthma patients requires comprehensive history, a thorough physical examination, and Pulmonary Function Tests (PFTs). ${ }^{3,7}$

The pharmacotherapy of asthma employs drugs aimed at reducing airway inflammation (antiinflammmatory agents) and at decreasing bronchospasm (bronchodilators). Six classes of therapeutic agents are presently indicated for asthma treatment which include Bronchodilators ( $\beta$ adrenergic agonists, Methylxanthines, Anticholinergics), Leukotriene antagonists, Mast cell stabilizers, Corticosteroids and Inhibitors of immunoglobulin E, Omalizumab. Salbutamol (Albuterol) is a highly selective $\beta_{2}$ agonist. This is a most effective drug in relaxing airway smooth muscle and reversing bronchoconstriction and preferred treatment for rapid symptomatic relief of dyspnea associated with asthmatic bronchoconstriction. The major adverse effects occur as a result of excessive activation of $\beta$-receptors. Tremors, feelings of restlessness, apprehension, anxiety, tachycardia, hypoxemia, increase in concentrations of glucose, lactate and free fatty acids and decrease in $\mathrm{K}^{+}$ concentration when given parenterally. ${ }^{8}$

Ocimum sanctum $L$. is an erect, hairy perennial shrub popularly known as sacred basil or holy basil, which is grown in temples, courtyards, for religious and medicinal purposes besides being cultivated for essential oil production. Indigenous to India and parts of north and eastern Africa, Hainan Island and Taiwan, China., ${ }^{9,10}$ The plant has many uses in ayurveda including asthma and cough. ${ }^{11}$ The main components are tannins $(4.6 \%)$ and essential oil (up to $2 \%$ ). Essential oil has methyl eugenol $(72.5 \%)$, eugenol (up to 62\%), thymol, ursolic acid $(3.221 \mathrm{mg} / \mathrm{g})$, ascorbic acid, carotene, $\beta$-caryophyllene $(5.5 \%)$, E-cinnamyl acetate $(3.4 \%)$, carvacrol and sisquiterpene alcohols as major constituents and terpene compounds, linoleic acid methylchavicol, linalool and 1, 8 -cineole as minor constituents. ${ }^{9,10,12-14}$

\section{Clinical study}

This study is conducted in normal subjects as well as asthmatic patients either by provoking bronchoconstriction with agents such as histamine, carbachol, methacholine, pollens, cold air and exercise induced etc. and by directly administering bronchodilator agents in asthmatic patients. The different lung volumes are measured before and after administering of drugs. ${ }^{15}$

Since the drugs available for the treatment of asthma so far though very effective, are also associated with adverse effects. Ocimum sanctum was shown to be effective in bronchial asthma in Ayurveda. Therefore, the present study is done to evaluate the antiasthmatic activity of Ocimum sanctum Linn. and to compare its efficacy with the standard bronchodilator drug, Salbutamol, in mild and moderate asthmatic patients.

\section{METHODS}

\section{Materials}

The following instruments and drugs were used in this clinical study:

\section{Instruments}

1. Mini spirometer SP-1A (Schiller, Switzerland)

2. Wright's mini peak flow meter (Airmed, London)

\section{Drugs}

1. Ocimum sanctum (OS) capsules

2. Salbutamol sulphate (SS) capsules

\section{Preparation of Ocimum sanctum capsules}

Fresh leaves of OS were collected and were authenticated by the botanist. They were washed, shade dried and made in to fine powder. Empty hard gelatin capsules which could contain $200 \mathrm{mg}$ of the drug were procured from the College of Nursing, KIMS, Hubli. 700 (as calculated for 50 patients on the basis of twice daily dose for seven days) such empty capsules were filled with $200 \mathrm{mg}$ dried leaf powder of OS, in the Department of Pharmaceutics, KLE's College of Pharmacy, Hubli. 


\section{Preparation of salbutamol capsules}

Another 700 hard gelatin capsules were selected and Salbutamol sulphate powder (Crystal Pharma, Hubli), 2 $\mathrm{mg}$, was filled in each of these. The remaining $198 \mathrm{mg}$ of each Salbutamol filled capsule was made up by adding the excipient, lactose.

Both OS and Salbutamol sulphate capsules were similar to each other in appearance.

\section{Preliminary studies}

To arrive at the dosage of $O S$ to be used in this clinical study, 6 patients were selected. In two patients $100 \mathrm{mg}$ of $O S$ powder was administered orally twice daily, in two patients $200 \mathrm{mg}$ of $O S$ capsules twice daily, and in last two patients, $200 \mathrm{mg}$ capsules of OS, thrice daily were administered. There was equal improvement in $\mathrm{FEV}_{1}$ and PEFR values with both $200 \mathrm{mg}$ twice daily group and 200 $\mathrm{mg}$ thrice daily group, whereas, $100 \mathrm{mg}$ twice daily group showed less improvement than the other two groups. There were no side effects in any of three groups. Based on these results, $200 \mathrm{mg}$ twice daily dose was decided to be evaluated in the clinical study.

\section{Dose selection}

The dose selection of $O S$ was based on the results of acute toxicity studies conducted in animals by Bhargava and Singh; in this study, $\mathrm{LD}_{50}$ of $O S$ leaves' extract in mice was reported to be $4508 \pm 80 \mathrm{mg} / \mathrm{kg}$ orally, as reported in Medicinal plants of India and the results of clinical trials conducted by S K Das, in which the dose of approximately $416 \mathrm{mg}$ was administered in patients with viral encephalitis. ${ }^{16,17}$ Based on these results, extrapolation of the dose was done and was found to be approximately $3 \mathrm{mg} / \mathrm{kg}$ body weight in humans.

\section{Screening of patients}

The screening of the patients for asthma was done in outpatient department of Medicine, KIMS, Hubli. The screening was done by obtaining a detailed history and performing general physical examination, respiratory system examination and PFTs. The grading of severity of asthma was done according to NAEPP classification system. ${ }^{18}$ The selection of patients was based on the following inclusion and exclusion criteria.

\section{Inclusion criteria}

Patients aged between 18 and 50 years, with a history of bronchial asthma of minimum 2 years, with mild and moderate asthma whose lung function tests mainly, $\mathrm{FEV}_{1}$ values more than $80 \%$ and not less than $60 \%$ of their predicted values adjusted for age, sex, and height, and who demonstrated at least $12-15 \%$ improvement in $\mathrm{FEV}_{1}$ above baseline measured 15 minutes following 100-400 $\mu \mathrm{g}$ of Salbutamol inhalation were included. ${ }^{19}$

\section{Exclusion criteria}

Patients below 18 years and above 50 years of age, those suffering from respiratory diseases other than asthma, cardiovascular, hepatic, renal, neurological diseases or acute lung infections, and those with history of smoking or alcohol consumption.

A total of 50 patients were thus selected for the clinical study based on all above criteria.

\section{Design of the study}

This was a 'single-blind cross-over' clinical study, conducted for a period of 3 weeks in each patient; both drugs (OS and SS) were administered for one week each, with a washout interval of one week between two drug regimens. The study protocol was approved by the Institutional Ethics Committee. Informed consent was obtained from each patient prior to the study.

Routine investigations of blood ( $\mathrm{Hb} \%$, TC, DC, ESR, AEC), urine (albumin, sugar, microscopy), and stools (ova, cyst) and chest X-Ray, PA view before the drug administration. Patients were advised not to take any medicine for 24 hours prior to the study. On the day of beginning of study, before administration of either drug $\left(D_{0}\right)$, pulse rate, blood pressure, respiratory rate, height, and weight of patients were recorded and respiratory system was examined. $\mathrm{FEV}_{1}$ was measured using a portable mini spirometer (SP-1A Schiller, Switzerland). Three readings were taken with a minimum of two minutes interval in between each recording. The best of three readings was taken in to consideration. The results were expressed in Litres (L). PEFR was measured using Wright's mini peak flow meter (Airmed, London). Three readings were taken at an interval of two minutes between each reading. The best of three readings was taken. The results were expressed in Litres/minute (L/min).

Each patient was then randomly assigned one of the following two treatment schedules:
a) 14 Salbutamol sulphate (SS) capsules
b) 14 Ocimum sanctum $(O S)$ capsules

Patients were advised to take the prescribed drugs twice daily and to be on their normal diet. Patients were also advised to take Salbutamol inhalation if there were any acute exacerbations of asthma or to visit the nearest hospital, if it was still not controlled. They were told to come for follow-up examination on $4^{\text {th }}$ day and $7^{\text {th }}$ day and to take the drug one and half hours before coming for examination on these days.

On $4^{\text {th }}$ day $\left(D_{4}\right)$ and 7 th day $\left(D_{7}\right)$, the vital parameters (respiratory rate, pulse, BP) were measured and PFTs were carried out and recorded. The patient compliance was noted by counting the remaining capsules. Patients 
were questioned about the improvement in symptoms of asthma and any side effects of the drug like nausea, vomiting, headache, palpitation, tremors, etc. or any other effect the patient experienced during the course of the drug therapy. After 7 th day, patients were allowed a washout period of seven days during which no drug was administered. The patients were advised to take Salbutamol inhalation if there were any acute exacerbations of asthma or to visit to the nearest hospital. After washout period, patients were subjected to the next drug regimen ' $\mathrm{B}$ ' or ' $\mathrm{A}$ ' as the case may be and the same protocol was repeated.

After the completion of the trial, the patients were asked about the preference of the drug and the reasons for preferring the drug.

\section{Statistical analysis}

The results of this study were expressed as Mean (Standard Deviation) [Mean (SD)] of various parameters of patients who completed the study. Results were analyzed by Student's paired and unpaired ' $t$ ' test. Significance was established when probability value ( $P$ value) was less than 0.05 . $\mathrm{P}$ values were denoted as $* \mathrm{P}$ $<0.05$ as significant and $* * \mathrm{P}<0.01$ as highly significant and $* * * \mathrm{P}<0.001$ as very highly significant.

\section{RESULTS}

The present clinical study was carried out in association with the Department of Medicine, Karnataka Institute of Medical Sciences (KIMS), Hubli, Karnataka.

The study was conducted between November 2007 and October 2008, in the OPD/IPD of Department of Medicine, at KIMS, Hubli, Karnataka. A total of 50 patients were selected for the study; out of which 41 patients attended the study completely which included 11 males, 30 females; 9 patients failed to attend the followup at various levels of the study and they were dropped out of the study. Their Mean (SD) age was 40.41 \pm 9.3 years. Out of 41 patients screened, 12 patients had mild asthma and 29 patients had moderate asthma.

Table 1 show the $\mathrm{FEV}_{1}$ and PEFR values before $\left(\mathrm{D}_{0}\right)$, on $4^{\text {th }}$ day and $7^{\text {th }}$ day of administration of Ocimum sanctum $(O S)$. Table 2 show the $\mathrm{FEV}_{1}$ and PEFR values before, and on $4^{\text {th }}$ and $7^{\text {th }}$ day of administration of Salbutamol Sulphate (SS) capsules.

Table 3 shows the comparison of the improvement of $\mathrm{FEV}_{1}$ and PEFR following Ocimum sanctum capsules. As shown in Table 3, there is significant difference in the $\mathrm{FEV}_{1}$ and PEFR values on day 4 and highly significant difference on day 7 , following Ocimum sanctum administration.

Table 4 shows the comparison of the improvement of $\mathrm{FEV}_{1}$ and PEFR following Salbutamol sulphate capsules.
As shown in Table 4, the difference in the $\mathrm{FEV}_{1}$ and PEFR values on day 4 are highly significant and very highly significant on day 7 , following Salbutamol sulphate administration.

Table 1: $\mathrm{FEV}_{1}$ and PEFR values before $\left(\mathrm{D}_{0}\right)$, on $4^{\text {th }}$ day and $7^{\text {th }}$ day of administration of Ocimum sanctum.

\begin{tabular}{|lllllll|}
\hline SI. & FEV & (Litres) & & \multicolumn{3}{l|}{ PEFR (Litres/min) } \\
No & $\mathbf{D}_{\mathbf{0}}$ & $\mathbf{D}_{\mathbf{4}}$ & $\mathbf{D}_{\mathbf{7}}$ & $\mathbf{D}_{\mathbf{0}}$ & $\mathbf{D}_{\mathbf{4}}$ & $\mathbf{D}_{7}$ \\
\hline 1 & 2.1 & 2.3 & 2.4 & 250 & 270 & 280 \\
\hline 2 & 1.4 & 1.5 & 1.6 & 190 & 210 & 230 \\
\hline 3 & 2 & 2 & 2 & 260 & 260 & 260 \\
\hline 4 & 2.1 & 2.3 & 2.3 & 250 & 270 & 280 \\
\hline 5 & 1.5 & 1.5 & 1.5 & 190 & 190 & 190 \\
\hline 6 & 2.4 & 2.5 & 2.6 & 290 & 310 & 330 \\
\hline 7 & 1.9 & 2.1 & 2.2 & 240 & 260 & 270 \\
\hline 8 & 2.2 & 1.8 & 1.7 & 250 & 200 & 200 \\
\hline 9 & 1.9 & 2 & 2.1 & 240 & 250 & 260 \\
\hline 10 & 1.7 & 1.9 & 1.9 & 230 & 250 & 250 \\
\hline 11 & 2.5 & 2.7 & 2.7 & 310 & 330 & 350 \\
\hline 12 & 1.7 & 1.7 & 1.7 & 250 & 250 & 250 \\
\hline 13 & 1.9 & 2.1 & 2.2 & 260 & 280 & 300 \\
\hline 14 & 2.4 & 2.6 & 2.6 & 360 & 380 & 390 \\
\hline 15 & 1.9 & 2.1 & 2.2 & 240 & 260 & 270 \\
\hline 16 & 2.6 & 2.8 & 2.8 & 370 & 390 & 390 \\
\hline 17 & 1.3 & 1.5 & 1.5 & 170 & 190 & 190 \\
\hline 18 & 1.7 & 1.8 & 1.9 & 230 & 250 & 260 \\
\hline 19 & 1.9 & 2.1 & 2.1 & 250 & 260 & 270 \\
\hline 20 & 2.1 & 1.7 & 1.6 & 260 & 220 & 210 \\
\hline 21 & 1.4 & 1.4 & 1.5 & 190 & 200 & 200 \\
\hline 22 & 2.5 & 2.6 & 2.7 & 350 & 370 & 380 \\
\hline 23 & 2.5 & 2.7 & 2.7 & 310 & 330 & 330 \\
\hline 24 & 2.5 & 2.1 & 2 & 340 & 290 & 270 \\
\hline 25 & 2.2 & 2.3 & 2.4 & 270 & 290 & 300 \\
\hline 26 & 1.8 & 1.9 & 2 & 240 & 260 & 270 \\
\hline 27 & 1.5 & 1.6 & 1.7 & 210 & 230 & 250 \\
\hline 28 & 1.4 & 1.5 & 1.6 & 190 & 210 & 220 \\
\hline 29 & 2.3 & 2.3 & 2.3 & 330 & 330 & 330 \\
\hline 30 & 1.8 & 2 & 2.1 & 250 & 270 & 280 \\
\hline 31 & 3.1 & 3.3 & 3.4 & 400 & 420 & 430 \\
\hline 32 & 2.3 & 1.9 & 1.8 & 330 & 290 & 260 \\
\hline 33 & 2.5 & 2.7 & 2.8 & 340 & 360 & 380 \\
\hline 34 & 2.2 & 2.3 & 2.4 & 260 & 280 & 290 \\
\hline 35 & 2.2 & 2.2 & 2.2 & 250 & 270 & 270 \\
\hline 36 & 2 & 2.2 & 2.2 & 260 & 280 & 280 \\
\hline 37 & 1.3 & 1.5 & 1.5 & 180 & 190 & 180 \\
\hline 38 & 1.4 & 1.5 & 1.5 & 200 & 220 & 210 \\
\hline 39 & 2.6 & 2.8 & 2.9 & 370 & 400 & 400 \\
\hline 41 & 2.4 & 1.9 & 1.9 & 370 & 320 & 310 \\
\hline & & & & & & \\
\hline
\end{tabular}

When the results of $4^{\text {th }}$ and $7^{\text {th }}$ days following Ocimum sanctum and salbutamol are compared, the latter showed highly significant improvement over Ocimum sanctum. 
Table 2: FEV $_{1}$ and PEFR values before, and on $4^{\text {th }}$ and $7^{\text {th }}$ day of administration of Salbutamol Sulphate (SS) capsules.

\begin{tabular}{|lllllll|}
\hline SI. & FEV $_{\mathbf{1}}$ (Litres) & & \multicolumn{3}{l|}{ PEFR (Litres/min) } \\
\hline No. & $\mathbf{D}_{\mathbf{0}}$ & $\mathbf{D}_{\mathbf{4}}$ & $\mathbf{D}_{\mathbf{7}}$ & $\mathbf{D}_{\mathbf{0}}$ & $\mathbf{D}_{\mathbf{4}}$ & $\mathbf{D}_{\mathbf{7}}$ \\
\hline 1 & 2.2 & 2.5 & 2.6 & 250 & 280 & 290 \\
\hline 2 & 1.4 & 1.6 & 1.7 & 190 & 220 & 240 \\
\hline 3 & 1.9 & 2.2 & 2.3 & 260 & 280 & 300 \\
\hline 4 & 2.1 & 2.4 & 2.5 & 250 & 280 & 300 \\
\hline 5 & 1.5 & 1.8 & 1.8 & 190 & 220 & 240 \\
\hline 6 & 2.5 & 2.7 & 2.7 & 290 & 290 & 290 \\
\hline 7 & 2 & 2 & 2 & 270 & 300 & 310 \\
\hline 8 & 2.1 & 1.8 & 1.7 & 250 & 200 & 220 \\
\hline 9 & 1.8 & 2.1 & 2.2 & 240 & 280 & 300 \\
\hline 10 & 1.8 & 2.1 & 2.2 & 230 & 260 & 280 \\
\hline 11 & 2.6 & 2.6 & 2.6 & 310 & 310 & 310 \\
\hline 12 & 1.7 & 2 & 2 & 250 & 270 & 290 \\
\hline 13 & 1.9 & 2.2 & 2.4 & 260 & 300 & 310 \\
\hline 14 & 2.4 & 2.4 & 2.4 & 350 & 350 & 350 \\
\hline 15 & 2 & 2.3 & 2.4 & 240 & 270 & 290 \\
\hline 16 & 2.6 & 2.8 & 2.9 & 370 & 410 & 420 \\
\hline 17 & 1.4 & 1.6 & 1.8 & 170 & 210 & 220 \\
\hline 18 & 1.8 & 2.1 & 2 & 220 & 240 & 270 \\
\hline 19 & 1.9 & 2.1 & 2.2 & 250 & 290 & 290 \\
\hline 20 & 2.4 & 1.8 & 1.7 & 260 & 200 & 190 \\
\hline 21 & 1.4 & 1.7 & 1.9 & 190 & 240 & 270 \\
\hline 22 & 2.5 & 2.5 & 2.5 & 350 & 350 & 350 \\
\hline 23 & 2.6 & 2.8 & 2.9 & 310 & 340 & 350 \\
\hline 24 & 2.6 & 2.1 & 2 & 350 & 290 & 270 \\
\hline 25 & 2.2 & 2.5 & 2.7 & 280 & 320 & 350 \\
\hline 26 & 1.9 & 2.2 & 2.4 & 240 & 260 & 300 \\
\hline 27 & 1.6 & 1.9 & 1.9 & 230 & 260 & 280 \\
\hline 28 & 1.5 & 1.8 & 2 & 200 & 230 & 270 \\
\hline 29 & 2.2 & 2.4 & 2.4 & 320 & 340 & 360 \\
\hline 30 & 1.9 & 2.2 & 2.3 & 270 & 300 & 310 \\
\hline 31 & 3.3 & 3.6 & 3.7 & 420 & 450 & 470 \\
\hline 32 & 2.3 & 1.8 & 1.8 & 330 & 270 & 250 \\
\hline 33 & 2.4 & 2.7 & 2.8 & 320 & 350 & 380 \\
\hline 34 & 2.4 & 2.7 & 2.9 & 250 & 300 & 320 \\
\hline 35 & 2.1 & 2.3 & 2.4 & 240 & 280 & 290 \\
\hline 36 & 1.9 & 2.2 & 2.3 & 250 & 280 & 300 \\
\hline 37 & 1.4 & 1.7 & 1.8 & 200 & 220 & 240 \\
\hline 38 & 1.4 & 1.7 & 1.8 & 190 & 250 & 260 \\
\hline 39 & 2.6 & 2.9 & 3 & 370 & 400 & 440 \\
\hline 41 & 2.4 & 1.9 & 1.9 & 370 & 320 & 300 \\
\hline & & & & & & \\
\hline
\end{tabular}

\section{DISCUSSION}

$\mathrm{FEV}_{1}$ and PEFR were chosen for studying the antiasthmatic effects of OS and Salbutamol because these parameters are reliable, widely accepted, and they correlate with the progression of disease, use of health care, and severity of asthma. They are also easy to monitor and can be measured with portable instruments which are easily available. ${ }^{19}$

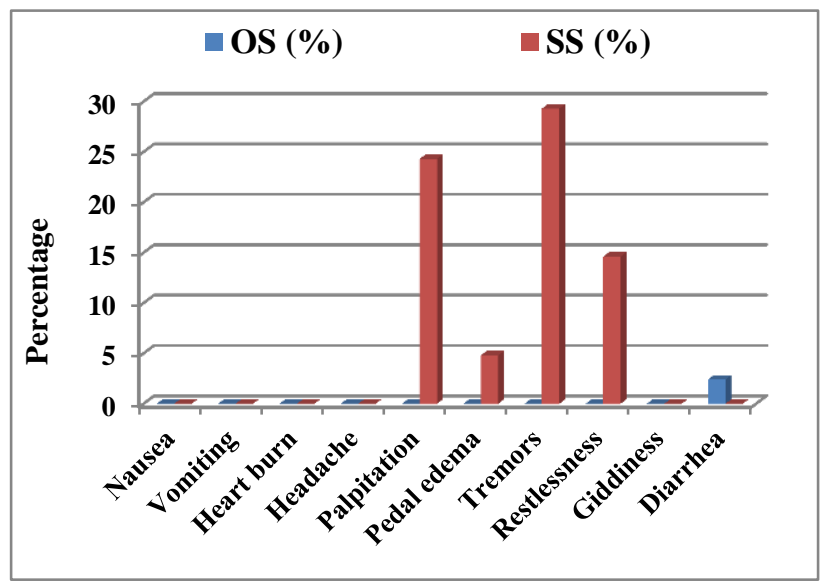

Figure 1: The percentage of adverse effects following Ocimum sanctum and salbutamol administration.

The significant antiasthmatic activity of OS may be due to a) its smooth muscle relaxant property which is attributed to elevation of cAMP in bronchial smooth muscle cells and due to blocking of replication of smooth muscle cells. ${ }^{20}$ Its smooth muscle relaxant property has also been shown on intestinal smooth muscle, when it was administered parenterally and orally, b) its property of modulating humoral responses at various levels in the immune system such as antibody production (IgE production in case of asthma), release of mediators of hypersensitivity reactions (such as histamine, PGs, LTs) and tissue response to these mediators, c) or its anti-stress properties, as reported by Bhargava and Singh, that $O S$ prevented stress induced ulcers in rats. ${ }^{21-23}$ Based on these studies and antistress properties of OS may be helpful in its efficacy in asthma. Activity of OS may be probably due to eugenol in the volatile oil. It may be predicted that hydroxy group on $4^{\text {th }}$ position of phenyl ring is responsible for bronchial smooth muscle relaxation. Presence of methoxy and propylene group on the phenyl ring may confer a maximum $\beta$-activity and selectivity. The presence of ursolic acid in the volatile oil may be responsible for anti-inflammatory activity, which may be due to inhibition of $\mathrm{COX}^{24}$

Six patients showed no improvement in their symptoms and lung function tests. The reason may be, decreased compliance in taking drugs by some of these patients or due to acute exacerbations during the therapy in some patients in which OS is not effective. But the exact reason is yet to be elucidated.

Nineteen patients complained of cough before the administration of OS of which nine patients showed improvement. This effect can be explained by its antitussive property, which could be due to presence of active ingradients of which saponins and ursolic acid are important. $^{25,26}$ This property also has been described in Indian materia medica by A.K. Nadkarni. 
Table 3: Comparison of the improvement of FEV1 and PEFR on $4^{\text {th }}$ and $7^{\text {th }}$ day following administration of Ocimum sanctum capsules.

\begin{tabular}{|lllllll|}
\hline & FEV & & PEFR & \\
& $\mathbf{D}_{\mathbf{0}}$ & $\mathbf{D}_{\mathbf{4}}$ & $\mathbf{D}_{\mathbf{7}}$ & $\mathbf{D}_{\mathbf{0}}$ & $\mathbf{D}_{\mathbf{4}}$ & $\mathbf{D}_{\mathbf{7}}$ \\
\hline Mean (SD) & $1.993(0.445)$ & $2.085(0.449)$ & $2.122(0.464)$ & $267.07(60.51)$ & $276.34(60.11)$ & $280.98(62.44)$ \\
\hline SEM & 0.069 & 0.07 & 0.073 & 9.45 & 9.39 & 9.75 \\
\hline \multirow{2}{*}{ P-value } & - & $\begin{array}{l}0.0202 \\
\text { (Significant) }\end{array}$ & $\begin{array}{l}0.0088 \text { (Highly } \\
\text { significant) }\end{array}$ & - & 0.01 & 0.0056 (Highly \\
significant)
\end{tabular}

Table 4: Comparison of the improvement of FEV1 and PEFR on $4^{\text {th }}$ and $7^{\text {th }}$ day following administration of Salbutamol sulphate capsules.

\begin{tabular}{|c|c|c|c|c|c|c|}
\hline & \multicolumn{3}{|l|}{$\mathrm{FEV}_{1}$} & \multicolumn{3}{|l|}{ PEFR } \\
\hline & $\mathrm{D}_{0}$ & $\mathbf{D}_{4}$ & $\mathbf{D}_{7}$ & $\mathbf{D}_{0}$ & $\mathbf{D}_{4}$ & $\mathbf{D}_{7}$ \\
\hline Mean (SD) & $2.056(0.439)$ & $2.198(0.413)$ & $2.28(0.441)$ & $268.54(59.86)$ & $287.07(55.46)$ & $300.97(56.87)$ \\
\hline SEM & 0.069 & 0.064 & 0.069 & 9.35 & 8.66 & 8.88 \\
\hline P-value & & $\begin{array}{l}0.0016 \text { (Highly } \\
\text { significant) }\end{array}$ & $\begin{array}{l}0.0001 \text { (Very } \\
\text { highly } \\
\text { significant) }\end{array}$ & & $\begin{array}{l}0.0004 \text { (Very } \\
\text { highly } \\
\text { significant) }\end{array}$ & $\begin{array}{l}0.0001 \text { (Very } \\
\text { highly } \\
\text { significant) }\end{array}$ \\
\hline
\end{tabular}

The highly significant bronchodilator activity of Salbutamol is due to various mechanisms such as, it activates $\beta_{2}$ receptors on human bronchial smooth muscle and causes the activation of $\mathrm{G}_{\mathrm{s}}$ adenylyl cyclase-cAMP pathway, which in turn activates Protein Kinase A. This causes the phosphorylation of cellular proteins resulting in the reduction of airway smooth muscle tone. Salbutamol also increases the conductance of large $\mathrm{Ca}^{2+}$ sensitive $\mathrm{K}^{+}$channels in airway smooth muscle, leading to membrane hyperpolarization and relaxation, and it inhibits the function of numerous inflammatory cells including mast cells, basophils, eosinophils, and neutrophils. These all mechanisms ultimately result in smooth muscle relaxation of the bronchial airways. ${ }^{8}$

The adverse effects such as, palpitations or tachycardia are due stimulation of cardiac $\beta_{1}$ receptors. ${ }^{8}$ Patient compliance of $>90 \%$ was observed with both drugs which may be due to the hope of getting a better drug for their treatment with least side effects. So, on comparing the results on $4^{\text {th }}$ and $7^{\text {th }}$ day of therapy with Ocimum sanctum and salbutamol, it is evident that both drugs increased $\mathrm{FEV}_{1}$ and PEFR values significantly on $7^{\text {th }}$ day as compared to the $4^{\text {th }}$ day of therapy. When compared to $\mathrm{SS}$, the activity of OS was less significant in the percentage increase on both $4^{\text {th }}$ and $7^{\text {th }}$ day and in producing bronchodilation and in relieving symptoms of asthma. The increase in $\mathrm{FEV}_{1}$ values on $7^{\text {th }}$ day of Ocimum sanctum (OS) therapy was approximately equivalent to that of Salbutamol Sulphate (SS) therapy on $4^{\text {th }}$ day.

\section{CONCLUSION}

The present clinical study shows that OS (Tulsi) dried leaves' powder contains the essential oil which contains constituents such as eugenol, methyleugenol, saponins and ursolic acid which may be responsible for the bronchodilator activity. Thus, OS (Tulsi) possesses antiasthmatic activity in mild and moderate asthma. Though it produced significant activity in mild and moderate asthma, the activity was less than that of Salbutamol, the standard drug, which was used for comparison in this study.

\section{ACKNOWLEDGEMENTS}

I am very much thankful to all my teachers and friends who helped me directly or indirectly in this research. I am greatly indebted to all patients who participated in this study.

\section{Funding: No funding sources}

Conflict of interest: None declared

Ethical approval: The study was approved by the Institutional Ethics Committee, KIMS, Hubli

\section{REFERENCES}

1. Boushey HA, Corry DB, Fahy JV. Asthma. In: Murray JF, Nadel JA. Textbook of medicine, $3^{\text {rd }}$ ed. Pennysylvania: WB Saunders Company; 2000;2:1247.

2. Murthy KJR, Sastry JG. Economic burden of asthma. NCMH background papers-burden of disease in India: 251-8.

3. McFadden ER. Asthma. In: Kasper DL, Braunwald E, Longo DL, Hauser HL, Jameson JL. Harrison's principles of internal medicine. $16^{\text {th }}$ ed; McGraw-Hill Companies, Inc; 2005;2:1508-11.

4. Aggarwal AN, Chaudhry K. Prevalence and risk factors for bronchial asthma in Indian adults: A 
multicentre study. Ind $\mathrm{J}$ Chest Dis Allied Sci. 2006;48:13-22.

5. Burney PGJ. Asthma: Epidemiology. In: Seaton Anthony, Seaton Douglas, Leitch Gordon. Crofton and Douglas's respiratory diseases, $5^{\text {th }}$ ed. Blackwell Science; 2000;2:894-7.

6. Fraser RS, Muller NL, Neil C, Pare PD. Asthma. In: Fraser and Pare's diagnosis of diseases of the chest $4^{\text {th }}$ ed. USA: W. B. Saunders Company; 1999;3:207897.

7. Tarlo SM, Balmes J, Balkissoon R, Beach J, Beckett $\mathrm{W}$, Bernstein D et al. Diagnosis and management of work-related asthma: ACCP Consensus statement. Chest. 2008;134(3):1S-41S.

8. Westfall TC, Westfall DP. Neurotransmission. The autonomic and somatic motor nervous systems. In: Brunton LL, Lazo JS, Parker KL. Goodman Gillman's Pharmacological basis of therapeutics, 11th ed. NewYork: McGraw-Hill Companies, Inc; 2006:167-8.

9. Satyavati. Ocimum Linn. In: Medicinal plants of India (monograph). New Delhi: I.C.M.R. publication; 1987;2:354-70.

10. Sancti FO. In: WHO monographs on selected medicinal plants; 2004.

11. Nadkarni KM. In: Dr. K. M. Nadkarni's Indian Materia Medica, $3^{\text {rd }}$ ed; Bombay: Popular Book Depot; 1954;1:861-7.

12. Kothari SK, Bhattacharya AK. Antimicrobial activity of essential oil of methyl eugenol rich Ocimum tenuiflorum L.F. (syn. O.sanctum 1). Indian drugs 2006;43(5):410-4.

13. Prakash P, Gupta N. Therapeutic uses of OS (Tulsi) with a note on eugenol and its pharmacological actions- A short review. Ind J Physiol Pharmacol. 2005;49(2):125-31.

14. Rao VKN, Gopalakrishnan V, Kishore, Prasad R, Srikanth P. Occurrence, distribution, and biological activity of Ursolic acid-A review. Indian Drugs. 2001;38(5):216-24.

15. Kudagi BL (Dissertation). Evaluation and comparison of bronchodilator activity of OS (Tulsi) in vitro and in vivo (clinical) study; Dharwad University, 1993:59-60.
16. Bhargava, Singh N. Antistress activity of Ocimum sanctum Linn. Ind J Med Res. 1981;73:443-51.

17. Das SK, Agarwal SS, Singh N. Ocimum sanctum (Tulsi) in the treatment of viral encephalitis. The Antiseptic. 1983;80(7):323-7.

18. Colice GL. Categorizing asthma severity: An overview of national guidelines. Clin Med and Res. 2004;2(3):155-63.

19. Blake K, Madbushi R, Derendorf H, Lima J. Population Pharmacodynamic model of Bronchodilator response to inhaled Albuterol in children and adults with asthma. Chest. 2008;134(5):981-7.

20. Hannan JMA, Marenah L, Ali L. OS leaf extracts stimulate insulin secretion from perfused pancreas, isolated islets and clonal pancreatic $\beta$ cells. J Endocrin. 2006;189:127-36.

21. Study of anti-tussive activity of Ocimum sanctum Linn in guinea pigs. Indian $\mathrm{J}$ Physiol Pharmacol. 2005;49(2):243-5.

22. Mediratta PK. Effect of Ocimum sanctum Linn. on humoral immune responses. Ind $\mathbf{J}$ Med Res. 1988;4:384-6.

23. Singh N. A new concept on the possible therapy of stress diseases with "adaptogens" (Anti-stress drugs) of indigenous plant origin. Current Medical Practice. 1981;25(1):50.

24. Singh H, Kapoor VK. In: Medicinal and Pharmaceutical chemistry. Delhi: Vallabh Prakashan; 1995.

25. Study of anti-tussive activity of Ocimum sanctum Linn in guinea pigs. Indian $\mathbf{J}$ Physiol Pharmacol; 2005;49(2):243-5.

26. Kokate CK, Purohit AP, Gokhale B. TerpenoidsTulsi. In: Pharmacognosy, $37^{\text {th }}$ edition; Pune: Nirali Prakashan, 2007:348-9.

Cite this article as: Vinaya M, Kudagi BL, Kamdod MA, Swamy M. Bronchodilator activity of Ocimum sanctum Linn. (tulsi) in mild and moderate asthmatic patients in comparison with salbutamol: a singleblind cross-over study. Int J Basic Clin Pharmacol 2017;6:511-7. 